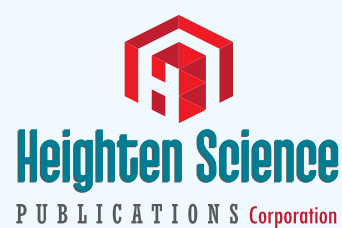

ISSN

2640-284X
*Address for Correspondence: Md. Sadikuj Jaman, Lab Science Diagnostics, 153/1, Green Road, Dhanmondi, Dhaka-1205, Bangladesh, Tel: +8801722793579; Fax: 07136474298; E-mail: sadik09bio.ru19@gmail.com sohanbmb.ru@gmail.com

Submitted: 28 December 2017

Approved: 05 January 2018

Published: 08 January 2018

Copyright: @ 2018 Jaman MS, et al. This is an open access article distributed under the Creative Commons Attribution License, which permits unrestricted use, distribution, and reproduction in any medium, provided the original work is properly cited

Keywords: Packed cell volume; Mean corpuscular volume; Mean corpuscular Hemoglobin concentration; Red blood cell Distribution width; HbA1c

Abbreviation: MCV: Mean Corpuscular Volume; RDW: Red blood cell Distribution Width; $\mathrm{MCH}$ : Mean Corpuscular Hemoglobin; PCV: Packed Cell Volume; MCHC: Mean Corpuscular Hemoglobin Concentration; RBC: Red Blood Cell; HbA1c: Glycolated Hemoglobin; FBG: Fasting Blood Glucose; RBS: Red Blood Cell; HDL: High Density Hemoglobin; LDL: Low Density Lipoprotein; SGOT: Serum Glutamic Oxaloacetic Transaminase; SGPT: Serum Glutamic Pyruvic Transaminase; TG: Triglycerides; CBC: Complete Blood Count; MPV: Mean Platelet Volume; DMT2: Diabetes Mellitus Type 2

Check for updates
Research Article

\section{Diabetes and red blood cell parameters}

\author{
Md. Sadikuj Jaman ${ }^{1,2^{\star}}$, Md. Sohanur Rahman ${ }^{2,3}$, Rubaiya
} Rafique Swarna' ${ }^{2}$, Joyanto Mahato ${ }^{2}$, Md. Milon Miah ${ }^{2}$ and Mosa. Ayshasiddeka ${ }^{2}$

'Department of Lab Science Diagnostics, 153/1, Green Road, Dhanmondi, Dhaka-1205, Bangladesh

${ }^{2}$ Department of Biochemistry and Molecular Biology, University of Rajshahi, Rajshahi-6205, Bangladesh

${ }^{3}$ Graduate School of Innovative Life Science, University of Toyama, 3190 Gofuku, Toyama 9308555, Japan

\section{Abstract}

Type 2 diabetes is a common disease in these days and day by day it is arising. The main focus of the study was to investigate association of packed cell volume (PCV), Mean Corpuscular Volume (MPV), Mean Corpuscular Hemoglobin Concentration $(\mathrm{MCHC})$, Red Cell Distribution Width (RDW) with glycemic marker $\mathrm{HbA} 1 \mathrm{c}$. So that PCV, MPV, MCHC, RDW could be used as a predictor of glucoregulation in type 2 diabetes instead of HbA1c value. This study included 87 DMT2 patients, which divided into two groups, $A$ ( $n=41$, presence in diabetics $\leq 6.5-6.9 \%)$ and $B(n=46$, target in diabetes $\geq 7.0 \%)$, according to HbA1c values. Spearsman correlation co-efficients were calculated to evaluate the relationship between RBC count, MCHC, RDW with random blood sugar (RBS) and PCV, MCV, MCHC with HbA1c value. Binominal logistic regression analysis was performed to estimate the relationship between glycemic control, as dichotomous outcome of MCHC, RDW, PCV, and MCV as the main prognosticator. $\mathrm{MCHC}$ and $\mathrm{RDW}$ were significantly higher in the group $\mathrm{B}$ compared to the group $\mathrm{A}$. RDW and $\mathrm{MCHC}$ may be applied as the auxiliary indicators of deterioration of glucoregulation.

\section{Introduction}

Type 2 diabetes is a metabolic disorder caused either by the insufficient production of insulin in islet cells of the pancreas or by resistance against secreted insulin in tissue, leading to an elevation in the glucose concentration in blood. Several research have been published that plasma cholesterol level, blood pressure, micro albumin urea and hyperglycemia are closely associated with the progression of diabetes mellitus $[1,2]$. Supernumerary, serum uric acid level, carboxyl terminal pro peptide and retinal venular diameter also used significant indicators of diabetic complications [3,4]. Red cell distribution width (RDW) is a quantative measure of variability in the size of circulating erythrocytes in cell sizes. Most interesting fact is that, RDW is a routinely reported to physicians in clinical practice as part of the automated complete blood count (CBC), It is mainly used as an auxiliary index in the differential diagnosis of macro cytic anemia. Iron deficiency anemia is associated with a high RDW. In addition to, thalassemia syndrome produce red blood cells (RBCs) of more homogenous size. Researchers have been demonstrated that higher or even normal reference range of RDW was even normal reference range of RDW was strongly associated with increased risk of cardiovascular disease (CVD) events in middle aged and older adults [5-11]. Recent studies have been demonstrated that RDW may also be an effective prognicator of morbidity and mortality in various disease such as $\mathrm{P}^{\mathrm{H}}[12,13]$, NAFLD[14], CHD [7,15-18], Stoke [19], atherosclerosis [20], prevalent dementia [21], IBD [22], ESRD 
[23] and heart failure [24]. On the other hand, HbA1c is a marker of long term glucose homeostasis and is routinely used to assess the adequacy of glycemic control in diabetic patients. Many researches have been noted that $\mathrm{HbA1c}$ is associated with type 2 diabetes patients. As well as, HbA1c is a marker of long term glucose homeostasis and is routinely used to assess the adequacy of glycemic control in diabetic patients. [25-27]. HbA1c level increase with age, chronic subclinical inflammation and possibly oxidative stress and also in conditions that can adversely affect red blood cell survival. For example, hemolytic anemia, blood transfusion (BT0, chronic malaria or major blood loss) [25,28,29]. Platelets, another element of the complete blood count (CBC), play a key role in the development of atherothrombosis, a major role in intravascular thrombosis on top of atherosclerosis, resulting in cardiovascular diseases in diabetes with respect to altered platelet morphology and function [30,31]. Mean platelet volume (MPV) is and indiactor of the average size and was suggested as an indicator of platelet activity and the state of thrombogenesis $[32,33]$. Some studies antiplaletes have been demonstrated as to be very effective at decreasing myocardial infarction, stroke and death [34]. In addition to, leukocytes are cognizant as to participate in the inflammatory process. Accompanying atherosclerosis. They are come round at the site of endothelial injury and form foam cells in the atherosmatosis plaque. WBC count is positively associated with increased cardiovascular mortality, mainly from coronary heart disease [35]. Previously our researches have been shown the association of mean platelet volume and platelet parameter with HbA1c [36]. In this study, we aimed to evaluate the relationship between RBC parameter such as RBC count, PCV, MCV, $\mathrm{MCHC}, \mathrm{RDW}-\mathrm{CV}$ and HbA1c value $\geq 7.5$ of diabetics' patients. So that $\mathrm{RBC}$ parameter could be used as prognicator of diabetes instead of $\mathrm{HbA1c}$ test.

\section{Material and Methods}

\section{Patients and research design}

The study was directed in Lab science Diagnostics, (153/1, Green Road, Dhanmondi, Dhaka-1205, Bangladesh). The study included 87 diabetic patients at least 5-6 months duration of diabetes from 02 April 2017 to 14 July 2015. In order to alleviate the impact of the confounding factors, hematological disorders, pregnancy and malignancy were factors for exclusion from the study. According to HbA1c value patients were divided into two groups: Group A ( $\mathrm{n}=41 \mathrm{HbA1} \leq \leq 6.5-6.9)$ and group $(\mathrm{n}=46 \mathrm{HbA1} \mathrm{c} \geq 7.0)$. Demographic clinical and laboratory data including age, gender, complete blood cell count, PCV(HCT), MCV, CMH, MCHC, RDW-CV, RBC count, fasting blood glucose (FBG), Random Blood Sugar (RBS), HbA1c and lipid profile (cholesterol, HDL, LDL and Triglycerides) in both groups were obtained.

\section{Applied tactics}

Blood cell count and HbA1c and other related parameters were measured. Blood samples were collected in tubes with EDTA anticoagulant. The tubes without anticoagulant were used for collecting blood for glucose and lipid profile measurement. Complete blood cell count was measured by sysmex XN-L series 350 (6 part). HbA1c value was measured by fine care ID chips. Lipid profile, glucose, and other biochemistry profile were measured by ERBA Mannheim XL 200. Fasting blood glucose was measured using a hexokinase method. Standardization, calibration of instrument and processing of samples were done according to manufacturer instructions. All Data reserve into MYSOFT LTD in Lab science Diagnostics. The study approval was taken from the ethics committee of Lab Science Diagnostics.

\section{Statistical Analysis}

Statistical analysis was performed by statistical packages for the social sciences (IBM SPSS Statistics) version 20 (Chicago, IL). All data were entered into excel program (Microsoft office 2007). IBM SPSS was used to find the significant difference of Fasting Blood Sugar (FBS), RBS, HbA1c, MPV, and PDW. Spearman's correlation 
coefficients were calculated to evaluate the relationship between MPV, PDW with HbA1c. Binominal logistic regression analysis was performed to assess independent relationship between RBC counts, PCV (HCT), MCV. CMH, MCHC, RDW-CV as the main prognosticator. The cut off value of PCV (HCT), MCV, CMH, MCHC and RDW-CV was determined for optimum sensitivity and specificity ratio of the diagnostic test. Positive and negative predictive values were calculated using recommended cut off value. Data were expressed as mean \pm standard deviation. $\mathrm{P}$ value was considered statistically significant.

\section{Result}

According to the result of sample population are detailed in table 1. A total of 87 patients fulfilling the selection criteria included 37 (out of $87,42.52 \%$ ) females and 50 (out of $87,57.47 \%$ ) males. The average age of both patients was 25 to 80 . The total number of study participants who were divided into two groups according to their diabetics status, 46 (out of 87, 52.87\%) DMT2 patients were in the group B (target in diabetics, $\mathrm{HbA1c}$ value $\geq 7.00$ ), 41 (out of $87,41.13 \%$ ) in the group A (presence in diabetics, HbA1c value $\geq 7.00$ ). Statistically significant differences were observed between those groups for various parameters. In this study, significant differences among the groups for all examined demographic and biochemical characteristics. Median value of age, FBS, RBS, HbA1c, platelet count, Cholesterol, LDL, Creatinine, SGPT, SGOT, Alkaline phosphatase, RBC count, MCHC, RDW CV were significantly higher in the group B compared to the group A. On the other hand, HDL, Triglycerides, PCV, MCV, MCH value in the group B compared to group A was found (Table 1).

Further analysis showed significant positive correlation between RBS count (\%) with RBS (mmol/L) in figure 1, MCHC (g/dL) with RBS (mmol/L) in figure 2, RDW CV (\%) with RBS (mmol/L) in Figure 3 in the total sample. On the other hand, PCV (\%) with HbA1c (\%) in figure 4, MCV (fL) with HbA1c (\%) in the figure 5, MCHC (g/dL) with $\mathrm{HbA1c}(\%)$ in the Figure 6 was drown in the sample. There were no correlations individually RBS, HbA1c, RBC count, PCV, MCHC, MCV and RDWCV in the group A or Group B.

Binominal logistic regression analysis model with PCV, MCV, MCHC and RDW as a predictor of deterioration of glucoregulation was statically significant, Indicating that

\begin{tabular}{|c|c|c|c|c|}
\hline Table 1: Characteristics and differences of the study participants. & & \\
\hline Characteristics/ Parameter & DMT2 & Group A(n=41) & Group B(n-46) & $\mathbf{P}=$ significance \\
\hline Age (Years) & $50 \pm 12.60$ & $48(25-75)$ & $55(35-80)$ & 0.265 \\
\hline Female/Male,n (\%) & $37 / 50$ & $16 / 25$ & $21 / 25$ & 0.011 \\
\hline FBG (mmol/L) & $10.8(6.1-18.9)$ & $6.9(6.1-6.85)$ & $11.65(6.8-18.9)$ & 0.255 \\
\hline RBS (mmol/L) & $17.7(6.8-29.8)$ & $7.25(1.20-14.20)$ & $17.7(6.8-29.8)$ & 0.955 \\
\hline HbA1c(\%) & $7.05(6.5-14.90)$ & $6.60(6.5-6.9)$ & $9.1(7-14.90)$ & 0.824 \\
\hline Platelet count (/ccm) & $274(10-559) \times 10^{3}$ & $268(150-559) \times 10^{3}$ & $277(10-554) \times 10^{3}$ & 0.190 \\
\hline Cholesterol (mg/dl) & $195(140-310)$ & $185(140-250)$ & $206(143-310)$ & 0.140 \\
\hline HDL (mg/dl) & $40(25-63)$ & $41.5(32-55)$ & $38.5(25-235)$ & 0.418 \\
\hline LDL (mg/dl) & $106.5(50-170)$ & $102(50-150)$ & $108(56-170)$ & 0.655 \\
\hline Triglycerides (mg/dl) & $209(11.5-1845)$ & $200(90-1180)$ & $198(11.5-1845)$ & 0.847 \\
\hline Creatinine (mg/dl) & $1.15(0.75-6.15)$ & $1.10(0.75-2.50)$ & $1.15(0.9-6.15)$ & 0.985 \\
\hline SGPT (U/L) & $48.37(20-235)$ & $37.63(20-65)$ & $55.75(23-235)$ & 0.005 \\
\hline SGOT(U/L) & $85(22-370)$ & $30(22-39)$ & $107(22-370)$ & 0.004 \\
\hline Alkaline Phosphatase (U/L) & $101.44(40-395)$ & $48(40-65)$ & $144.20(60-395)$ & 0.016 \\
\hline RBC count(million/cmm) & $4.54(1.22-7.09)$ & $4.51(2.95-5.49)$ & $4.56(1.22-7.09)$ & 0.608 \\
\hline PCV-HCT(\%) & $37.35(12.70-48.10)$ & $38.03(24-47.30)$ & $36.76(12.70-48.10)$ & 0.609 \\
\hline MCV(fL) & $83.06(60.60-104.10)$ & $84.25(60.60-92.30)$ & $82.02(61.10-104.10)$ & 0.073 \\
\hline MCH(pg) & $26.94(18.10-34.40)$ & $27.21(18.10-30.20)$ & $26.72(18.70-34.40)$ & 0.289 \\
\hline MCHC(g/dL) & $32.51(29.70-36.40)$ & $32.27(29.70-34.50)$ & $32.70(36.70-36.40)$ & 0.145 \\
\hline RDW-CV (\%) & $13.65(11.60-21.40)$ & $13.38(11.60-21.40)$ & $13.89(11.60-18.70)$ & 0.200 \\
\hline
\end{tabular}


Table 2: Optimal cut-off, sensitivity, specificity, accuracy, disease prevalence, positive predicting value (PPV) and negative predicting value (NPV) of PCV, MCV, MCHC, RDW in prognostication of Diabetics.

\begin{tabular}{|c|c|c|c|c|c|c|}
\hline \multicolumn{1}{|c|}{ Variable } & Sensitivity (\%) & Specificity (\%) & $\begin{array}{c}\text { Disease } \\
\text { Prevelence(\%) }\end{array}$ & Accuracy (\%) & NPV (\%) & PPV (\%) \\
\hline PCV(\%) (cut off -45) & 78.12 & 52.12 & 40.14 & 53.56 & 74.50 & 51.25 \\
\hline MCV (fL) (cut off-91) & 61.85 & 42.56 & 48.18 & 50.56 & 57.58 & 46.65 \\
\hline $\begin{array}{c}\text { MCHC(g/dL) (cut off } \\
-32.5)\end{array}$ & 58.44 & 48.52 & 51.18 & 44.78 & 41.48 & 53.76 \\
\hline RDW(\%) (cut off-13) & 68.80 & 38.94 & 52.66 & 46.99 & 47.59 & 55.91 \\
\hline
\end{tabular}

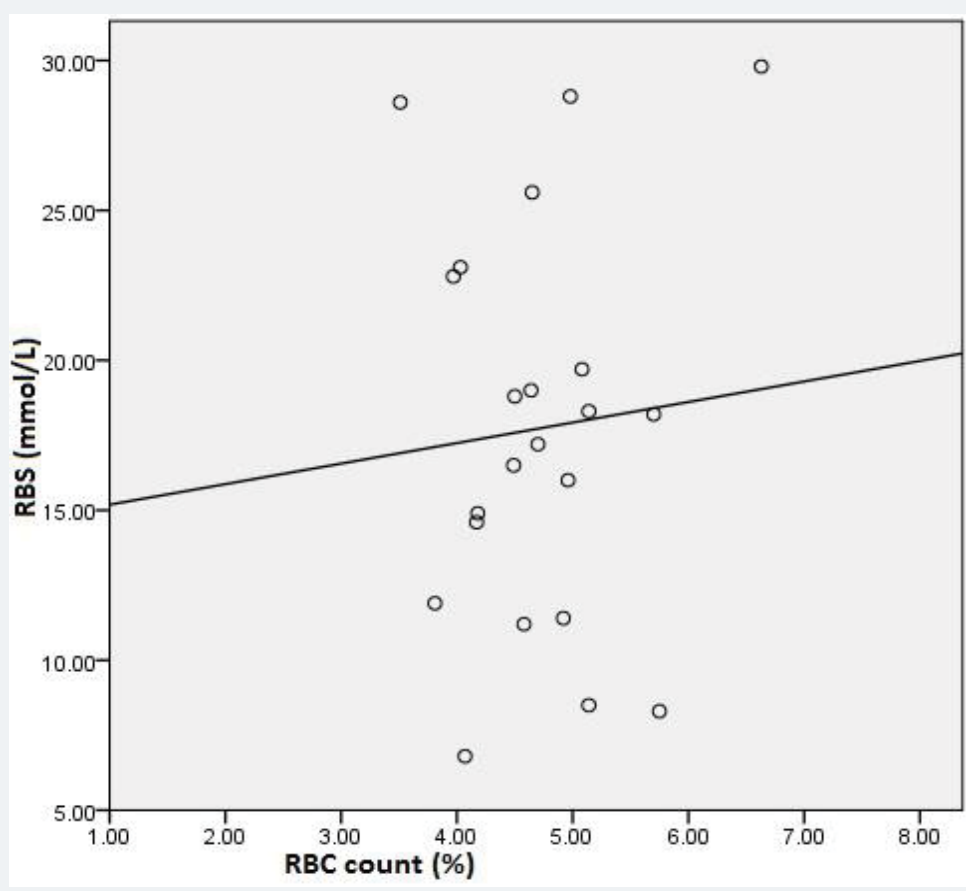

Figure 1: Correlation analysis between Red blood Cell count (RBC) and Random blood sugar (RBS) levels in the total sample.

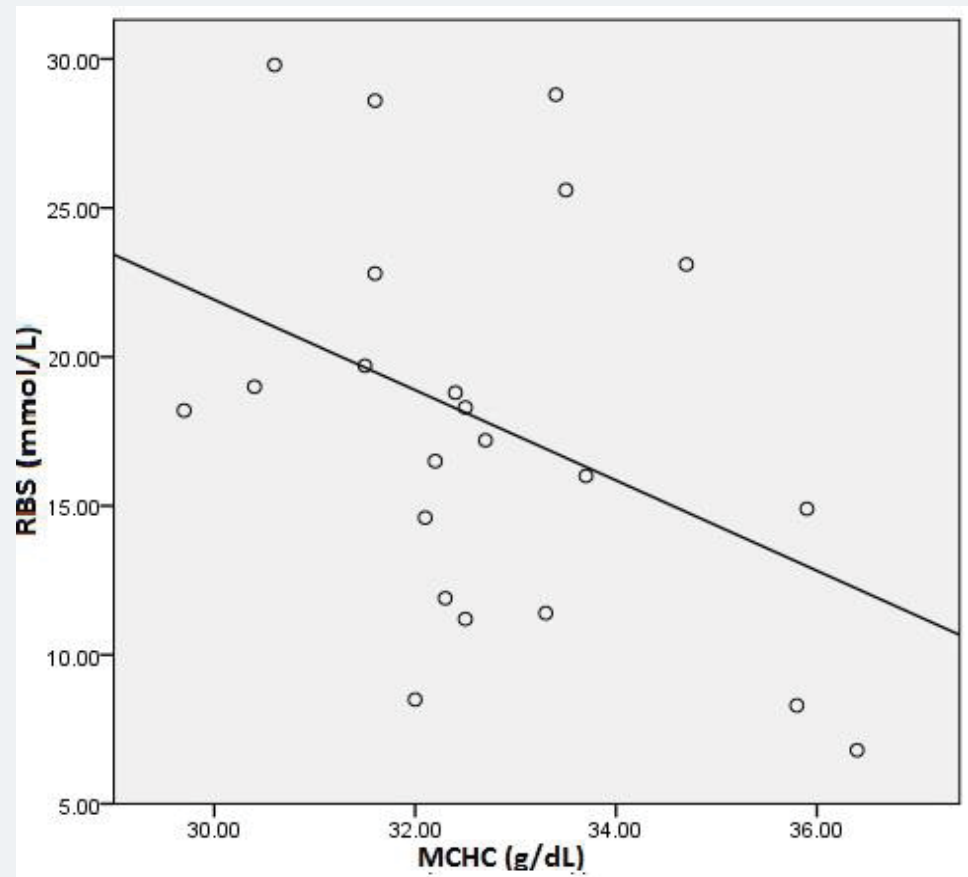

Figure 2: Correlation analysis between Mean Corpuscular Hemoglobin Concentration (MCHC) and Random blood sugar (RBS) levels in the total sample. 


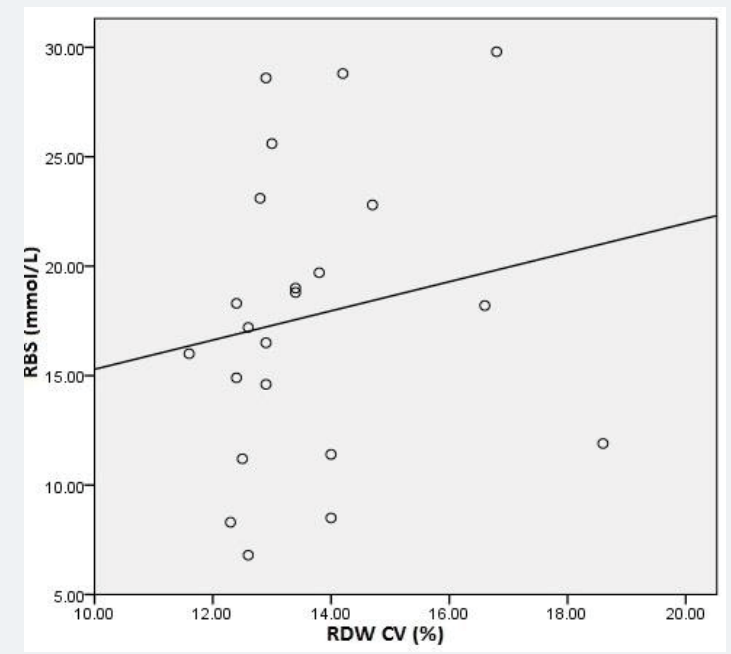

Figure 3: Correlation analysis between red blood cell distribution width (RDW CV) and Random blood sugar (RBS) levels in the total sample.

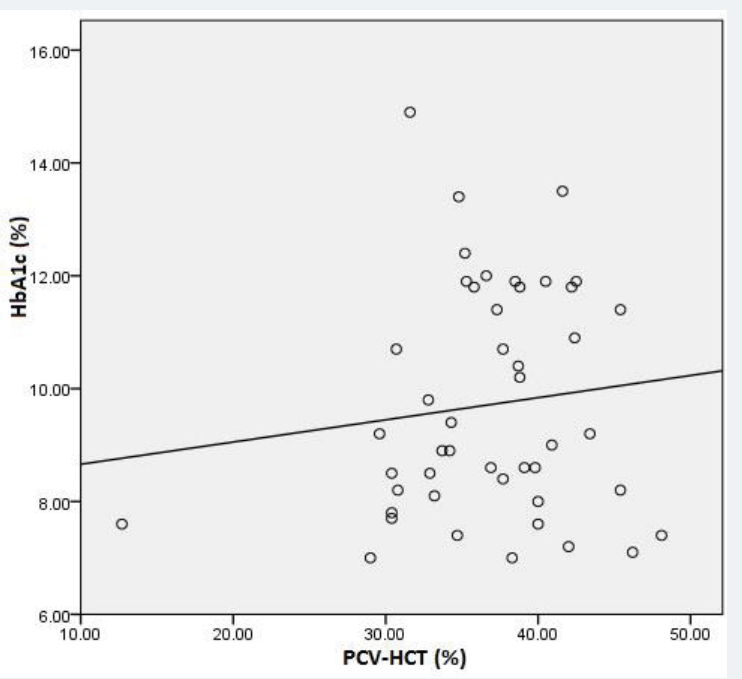

Figure 4: Correlation analysis between packed cell volume (PCV HCT) and glycated hemoglobin (HbA1c) levels in the total sample.

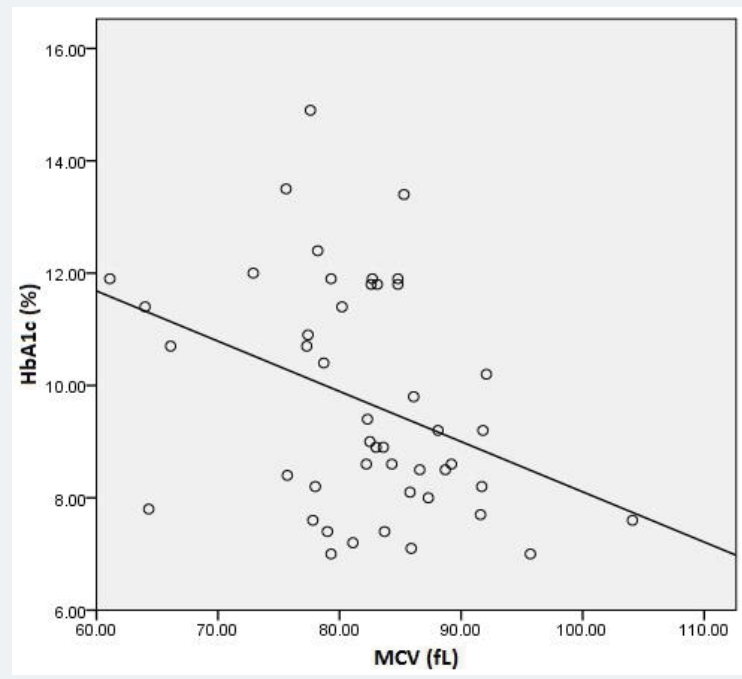

Figure 5: Correlation analysis between mean corpuscular volume (MCV) and glycated hemoglobin (HbA1c) levels in the total sample. 


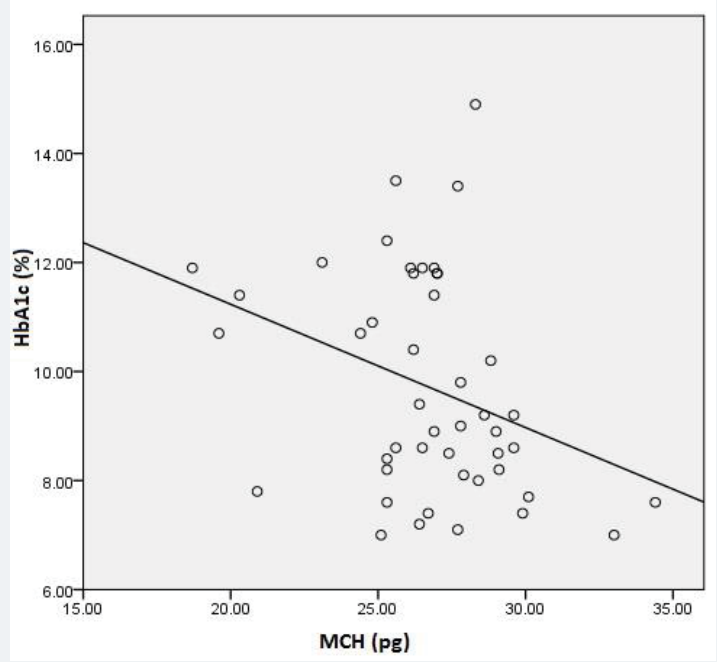

Figure 6: Correlation analysis between mean corpuscular hemoglobin $(\mathrm{MCH})$ and glycated hemoglobin $(\mathrm{HbA} 1 \mathrm{c})$ levels in the total sample.

MCHC, RDW distinguish patients with good (HbA1c $\leq 6.5-6.9)$ and poor $(\mathrm{HbA1c} \geq 7 \%)$ glucoregulation.

This model showed that the significant value of MCHC and RDW were positively associated with the risk of inadequate glycemic control.

\section{Discussion}

Our study is the first to demonstrate a significantly positive association between $\mathrm{MCH}$. MCHC, RDW with HbA1c independent of RBS levels in an adult general population with no history of diabetes and free of cardio vascular disease. HbA1c levels have also been shown to be associated with inflammation even in populations with no diabetes [10]. The RDW, a widely available and inexpensive test conducted as part of the complete blood cell count, measures the degree of anisocytosis. It is calculated as follows,

$\mathrm{RDW}-\mathrm{CV}=$ (standard deviation of red blood cell volume $\div$ mean cell volume) $\times 100$

The normal range for the RDW-CV is $11.5 \%$ to $14.5 \%$ and higher values indicate greater in cell sizes. High RDW indicates a high degree of anisocytosis which is associated with distortion and degredation of erythropoiesis [37]. Reflecting chronic inflammation and an increased level of oxidative stress. Increased RDW also arise as a result of anemia. Otherwise, causes like iron deficiency and megaloblastic anemia with associated micro or macro cytosis are potential cofounders because our patients were not screen for iron, vitamin 12, folic acid. Nevertheless, the effect of such confounders is negligible as all the participants selected for the study were healthy individuals and diabetes without complication or obvious co morbidities as at the time of the study. The effect of other causes of chronic inflammation for example tuberculosis, cancers and connective tissue disorders as confounders is similarly negligible. The life span of red blood cell could be decreased in diabetes patients. So, RBC's are affected by various disturbances in the hematopoietic milieu. These disturbances lead as to elevated internal viscosity and increased membrane rigidity in these blood cells. So, RBC count is calculated as increase.

Our studies indicate that PCV decreased significantly in diabetic patients $(\mathrm{HbA1} \geq \geq 7.5)$ when compared with non diabetic patients (HbA1c $\leq 6.5)$. The decreased in PCV value of diabetic patient may be due to the dehydration and accumulation of protein.

The result in this study showed significantly increased in MCH \& MCHC, some 
research have been suggested that anemia occurrence in diabetic mellitus is due to increased no enzymatic glycosylation of RBC membrane proteins, which correlated with hyperglycemic. Oxidation of these glycosylated membrane proteins and hyperglycemic in diabetes mellitus cause an increase in the production of lipid peroxides causing a hemolysis of RBCs or diabetes mellitus may cause anemia as secondary disorder

Also in contrast to these studies MCHC and RDW had been reported as a predictive marker reflecting an underlying inflammatory state [38]. High RDW and MCHC were strongly associated with poor clinical outcomes in patients with heart failure, coronary artery disease [11,39], pulmonary hyper tension and peripheral arterial disease [40]. Increased RDW and MCH also associated with increased mortality in diabetic patients with coronary artery disease treated with percutaneous coronary intervention.

\section{Conclusion}

$\mathrm{RBC}$ count, $\mathrm{PCV}, \mathrm{MCV}$ as an $\mathrm{RBC}$ index are down rising and $\mathrm{MCHC}$, RDW are uprising as a new marker associated with higher mortality in health and disease. In diabetic patients, the glycemic control does affect the MCHC and RDW. Good glycemic control is associated with lower RDW and MHC value than in patients with poor control. Both MCHC \& RDW are directly and significantly associated. This positive correlation may strengthen the notion that RDW is an inflammatory marker. The study in our population can be considered as an initial one that necessitates further studies to define the relation between RBC count, PCV, MCV, MCHC and RDW with different diabetic complications and its predictive value. Further studies are also required to define specific values of the RDW to indicate specific risks in diabetic patients.

\section{Acknowledgements}

The authors would like to thanks Lab Science diagnostic for sharing patients report.

\section{References}

1. Schmitz A. Microalbuminuria blood pressure, metabolic control, and renal involvement: longitudinal studies in white non-insulindependent diabetic patients. Am J Hypertens. 1997; 10; 189-197. Ref.: https://goo.gl/GqneQj

2. Ravid M, Brosh D, Ravid-Safran D, Levy Z, Rachmani R. Main risk factors for nephropathy in type 2 diabetes mellitus are plasma cholesterol levels, mean blood pressure, and hyperglycemia. Arch Intern Med. 1998; 158: 998-1004. Ref.: https://goo.gl/k26UT8

3. Chang $\mathrm{YH}$, Lei $\mathrm{CC}$, Lin $\mathrm{KC}$, Chang $\mathrm{DM}$, Hsieh $\mathrm{CH}$, et al. Serum uric acid level as an indicator for CKD regression and progression in patients with type 2 diabetes mellitus-a 4.6-year cohort study. Diabetes Metab Res Rev. 2016; 32: 557-564. Ref.: https://goo.gl/GtuDBE

4. Roy MS, Klein R, Janal MN. Retinal venular diameter as an early indicator of progression to proliferative diabetic retinopathy with and without high-risk characteristics in African Americans with type 1 diabetes mellitus. Arch Ophthalmol. 2011; 129: 8-15. Ref.: https://goo.gl/24dvub

5. Anderson JL, Ronnow BS, horne BD, Carlquist JF, May HT, et al. Usefulness of a complete blood count-derived risk score to predict incident mortality in patients with suspected cardiovascular disease. Am J Cardiol. 2007; 99: 169-174. Ref.: https://goo.gl/DKomPT

6. Ani C, Ovbiagele B. elevated red blood cell distribution width predicts mortality in persons with known stroke. J Neurol Sci. 2009; 277: 103-108. Ref.: https://goo.gl/2qQD38

7. Cavusoglu e, Chopra V, Gupta A, Battala V R, Poludasu S, et al. Relation between red blood cell distribution width (RDW) and all-cause mortality at two years in an unselected population referred for coronary angiography. Int J Cardiol. 2009; 28: 141-146. Ref.: https://goo.gl/vXBgJM

8. Felker GM, Allen LA, Pocock SJ, Shaw LK, McMurray JJ, et al. Red cell distribution width as a novel prognostic marker in heart failure: data from the ChARM Program and the Duke Databank. J Am Coll Cardiol. 2007; 50: 40-47. Ref.: https://goo.gl/J1Prsp

9. Patel KV, Ferrucci L, Ershler WB, Longo DL, Guralnik JM. Red blood cell distribution width and the risk of death in middle-aged and older adults. Arch Intern Med. 2009; 169: 515-523. Ref.: https://goo.gl/LTcSmn 
10. Perlstein TS, Weuve J, Pfeffer MA, Beckman JA. Red blood cell distribution width and mortality risk in a community-based prospective cohort. Arch Intern Med. 2009; 169: 588-594. Ref.: https://goo.gl/p62Hg4

11. Tonelli M, Sacks F, Arnold M, Moye L, Davis B, et al. Relation between red blood cell distribution width and cardiovascular event rate in people with coronary disease. Circulation. 2008; 117: 1630-168. Ref.: https://goo.gl/KkSK7i

12. Hampole CV, Mehrotra AK, Thenappan T, Gomberg-Maitland M, Shah SJ. Usefulness of red cell distribution width as a prognostic marker in pulmonary hypertension. Am J Cardiol. 2009; 104: 868872. Ref.: https://goo.gl/YzeXAh

13. Rhodes CJ, Wharton J, Howard LS, Gibbs JS, Wilkins MR. Red cell distribution width outperforms other potential circulating biomarkers in predicting survival in idiopathic pulmonary arterial hypertension. Heart. 2011; 97: 1054-1060. Ref.: https://goo.gl/pR7AAn

14. Kim HM, Kim BS, Cho YK, Kim BI, Sohn $\mathrm{Cl}$, et al. Elevated red cell distribution width is associated with advanced fibrosis in NAFLD. Clin Mol Hepatol. 2013; 19: 258-265. Ref.: https://goo.gl/bN8YoA

15. Vaya A, Rivera L, de la Espriella R, Sanchez F, Suescun M, et al. Red blood cell distribution width and erythrocyte deformability in patients with acute myocardial infarction. Clin Hemorheol Microcirc. 2015; 59: 107-114. Ref.: https://goo.gl/kX9KB4

16. Veeranna V, Zalawadiya SK, Panaich S, Patel KV, Afonso L. Comparative analysis of red cell distribution width and high sensitivity C-reactive protein for coronary heart disease mortality prediction in multi-ethnic population: findings from the 1999-2004 NHANES. Int J Cardiol. 2013; 168 : 5156-5161. Ref.: https://goo.gl/Da4Eni

17. Tonelli M, Sacks F, Arnold M, Moye L, Davis B, et al. Relation Between Red Blood Cell Distribution Width and Cardiovascular Event Rate in People With Coronary Disease. Circulation. 2008; 117: 163168. Ref.: https://goo.gl/yFX8Po

18. Afsar B, Saglam M, Yuceturk C, Agca E. The relationship between red cell distribution width with erythropoietin resistance in iron replete hemodialysis patients. Eur J Intern Med. 2013; 24: 25-29. Ref.: https://goo.gl/4PEdNC

19. Soderholm M, Borne Y, Hedblad B, Persson M, Engstrom G. Red cell distribution width in relation to incidence of stroke and carotid atherosclerosis: a population-based cohort study. PLoS One. 2015; 10. Ref.: https://goo.gl/VQXsud

20. Wonnerth A, Krychtiuk KA, Mayer FJ, Minar E, Wojta J, et al. Red cell distribution width and mortality in carotid atherosclerosis. Eur J Clin Invest. 2016; 46: 198-204. Ref.: https://goo.gl/hVqR9r

21. Weuve J, M de Leon CF, Bennett DA, Dong X, Evans DA. The red cell distribution width and anemia in association with prevalent dementia. Alzheimer Dis Assoc Disord. 2014; 28: 99-105. Ref.: https://goo.gl/uG9tF6

22. Yesil A, Senateş E, Bayoğlu IV, Erdem ED, Demirtunç R, et al. Red cell distribution width: a novel marker of activity in inflammatory bowel disease. Gut Liver. 2011; 5: 460-467. Ref.: https://goo.gl/D48gvD

23. Yoon HE. Kim SJ, Hwang $\mathrm{H}$, Chung $\mathrm{S}$, Yang CW, et al. Progressive rise in red blood cell distribution width predicts mortality and cardiovascular events in end-stage renal disease patients. PLoS One. 2015; 10. Ref.: https://goo.gl/djpUFJ

24. Felker GM, Allen LA, Pocock SJ, Shaw LK, McMurray JJ, et al. Red cell distribution width as a novel prognostic marker in heart failure: data from the CHARM Program and the Duke Databank. J Am Coll Cardiol. 2007; 50: 40-47.Ref.: https://goo.gl/hf3oFN

25. Diagnosis and classification of diabetes mellitus. Diabetes Care. 2012; 35: 64-71.

26. Khaw KT, Wareham N. Glycated hemoglobin as a marker of cardiovascular risk. Curr Opin Lipidol. 2006; 17: 637-643. Ref.: https://goo.gl/bGQTSf

27. Selvin E, Steffes MW, Zhu H, Matsushita K, Wagenknecht L, et al. Glycated hemoglobin diabetes, and cardiovascular risk in nondiabetic adults. N Engl J Med. 2010; 362: 800-811. Ref.: https://goo.gl/KkLU4j

28. Debard A, Charmion S, Ben Ameur S, Gaultier JB, Cathebras P. Inappropriate low glycated hemoglobin and hemolysis (in French). Rev Med Interne. 2009; 30: 525-527. Ref.: https://goo.gl/KYzr41

29. Oda E. Bilirubin is negatively associated with A1C independently of fasting plasma glucose, age, obesity, inflammation, hemoglobin, and iron in apparently healthy Japanese men and women. Diabetes Care. 2010; 33: 131. Ref.: https://goo.gl/Z43kWD 
30. Montagnana M, Cervellin G, Meschi T, Lippi G. The role of red blood cell distribution width in cardiovascular and thrombotic disorders. Clin Chem Lab Med. 2011; 50: 635-641. Ref.: https://goo.gl/u1YAYN

31. Imani F, Horii Y, Suthanthiran M, Skolnik EY, Makita Z, et al. Advanced glycosylation end productspecific receptors on human and rat T-lymphocytes mediate synthesis of interferon $\mathrm{Y}$ : role in tissue remodelling. J Exp Med. 1993; 178: 2165-2172. Ref.: https://goo.gl/PtH7sw

32. Hekimsoy Z, Payzinb B, Ornek T, Kandogan G. Mean platelet volume in type 2 diabetic patients. J Diabetes Complications. 2004; 18: 173-176. Ref.: https://goo.gl/VEhqKn

33. Bae SH, Lee J, Roh KH, Kim J. Platelet activation in patients with diabetic retinopathy. Korean J Ophthalmol. 2003; 17: 140-144. Ref.: https://goo.gl/Evwq6d

34. Antithrombotic Trialists' Collaboration. Collaborative meta-analysis of randomised trials of antiplatelet therapy for prevention of death, myocardial infarction, and stroke in high risk patients. BMJ. 2002; 324: 71-86. Ref.: https://goo.gl/jBbMP4

35. Tong PC, Lee KF, So WY, Chan WB, Lo MK, et al. White blood cell count is associated with macro and microvascular complications in Chinese patients with type 2 diabetes. Diabetes Care. 2004; 27 : 216-222. Ref.: https://goo.gl/GCrNjW

36. Jaman S, Sawgat R, et al. Association of Mean Platelet Volume and Platelet Distribution Width with Hba1c. J Endocrinol Diab. 2017; 4: 1-6.

37. Evans TC, Jehle D. The red blood cell distribution width. J Emerg Med. 1991; 9: 71-74. Ref.: https://goo.gl/tPUvbQ

38. Dabbah S, Hammerman H, Markiewicz W, Aronson D. Relation between red cell distribution width and clinical outcomes after acute myocardial infarction. Am J Cardiol. 2010; 105: 312-317. Ref.: https://goo.gl/81cfec

39. Rhodes CJ, Wharton J, Howard LS, Gibbs JS, Wilkins MR. Red cell distribution width outperforms other potentials circulating biomarkers in predicting survival in idiopathic pulmonary arterial hypertension. Heart. 2011; 97: 1054-1060. Ref.: https://goo.gl/38XVV6

40. Ye Z, Smith C, Kullo IJ. Usefulness of red cell distribution width to predict mortality in patients with peripheral arterial disease. Am J Cardiol. 2011; 107: 1241-1245. Ref.: https://goo.gl/QZk4jW 